Managing Residential Child Care 
This page intentionally left blank 


\section{Managing Residential Child Care}

\section{A Managed Service}

Richard Whipp

Professor, Cardiff Business School, UK \& Pro Vice-Chancellor Cardiff University, UK

Ian Kirkpatrick

Senior Lecturer, Leeds University Business School, UK

Martin Kitchener

Assistant Professor, Department of Social \& Behavioural Sciences, University of

California, San Francisco, USA 


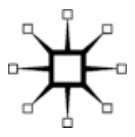

(C) Richard Whipp, lan Kirkpatrick and Martin Kitchener 2005

Softcover reprint of the hardcover 1st edition 2005 978-1-4039-3560-1

All rights reserved. No reproduction, copy or transmission of this publication may be made without written permission.

No paragraph of this publication may be reproduced, copied or transmitted save with written permission or in accordance with the provisions of the Copyright, Designs and Patents Act 1988, or under the terms of any licence permitting limited copying issued by the Copyright Licensing Agency, 90 Tottenham Court Road, London W1T 4LP.

Any person who does any unauthorised act in relation to this publication may be liable to criminal prosecution and civil claims for damages.

The authors have asserted their rights to be identified as the authors of this work in accordance with the Copyright, Designs and Patents Act 1988.

First published 2005 by

PALGRAVE MACMILLAN

Houndmills, Basingstoke, Hampshire RG21 6XS and

175 Fifth Avenue, New York, N.Y. 10010

Companies and representatives throughout the world.

PALGRAVE MACMILLAN is the global academic imprint of the Palgrave Macmillan division of St. Martin's Press, LLC and of Palgrave Macmillan Ltd. Macmillan ${ }^{\circledR}$ is a registered trademark in the United States, United Kingdom and other countries. Palgrave is a registered trademark in the European Union and other countries.

ISBN 978-1-349-51804-3 ISBN 978-0-230-50612-1 (eBook) DOI 10.1057/9780230506121

This book is printed on paper suitable for recycling and made from fully managed and sustained forest sources.

A catalogue record for this book is available from the British Library.

Library of Congress Cataloging-in-Publication Data

Whipp, Richard.

Managing residential child care: a managed service / Richard Whipp, Ian Krikpatrick, Martin Kitchener.

p. $\mathrm{cm}$.

Includes bibliographical references and index.

1. Children - Institutional care - Great Britain. 2. Institutional care Great Britain - Management. I. Kirkpatrick, lan, 1965- II. Kitchener, Martin, 1966- III. Title.

HV1144.W48 2005

$362.73^{\prime} 2^{\prime} 068-d c 22$

2004052106

$\begin{array}{llllllllll}10 & 9 & 8 & 7 & 6 & 5 & 4 & 3 & 2 & 1\end{array}$

$\begin{array}{llllllllll}14 & 13 & 12 & 11 & 10 & 09 & 08 & 07 & 06 & 05\end{array}$ 


\section{Contents}

List of Tables and Figures viii

Acknowledgements $\quad$ ix

1 Introduction $\quad 1$

1.1 Children's homes and their management 1

1.2 Book structure $\quad 5$

2 Understanding the External Management of $\begin{array}{ll}\text { Children's Homes } & 9\end{array}$

Introduction $\quad 9$

2.1 The management of children's homes by local authorities $\quad 9$

$\begin{array}{ll}2.2 & \text { What is management? } \\ \end{array}$

2.3 Management goals in children's residential care 16

2.4 A contingency approach to the management of children's homes $\quad 18$

2.5 Social service departments as professional bureaucracies 19

Conclusion $\quad 23$

3 The Study 25

$\begin{array}{ll}\text { Introduction } & 25\end{array}$

3.1 Project outline 26

3.2 Method 28

3.3 Sample 32

3.4 Supply and demand for residential care 38

$\begin{array}{ll}\text { Conclusion } & 45\end{array}$

4 Strategy and Implementation $\quad 49$

Introduction $\quad 49$

4.1 Strategy and residential care in social

4.2 Strategy and planning $\quad 54$

4.3 Creating strategic plans for children's services

$\begin{array}{ll}4.4 \text { Implementation } & 61\end{array}$

Conclusion $\quad 65$ 
5 The Management of Child Placement 69 Introduction $\quad 69$

5.1 The organisation of placement decision making 70

5.2 The 'problem' of placement decision making in SSDs

5.3 Approaches to child placement decision making in the 11 case SSDs

5.4 Comparing the effectiveness of different approaches to the management of child placement

Conclusion

6 Line Management $\quad 92$

Introduction $\quad 92$

6.1 The 'custodial' pattern of line management in children's services 93

6.2 Towards the reform of line management in children's residential care 95

6.3 The general characteristics of line management in the case SSDs 99

6.4 Management practice $\quad 105$

Conclusion 112

7 Managing and Developing Staff 116 Introduction 116

7.1 Managing staff and residential care 117

7.2 Personnel management and the public sector 119

7.3 Managing staff and residential care in the case authorities 120

$\begin{array}{ll}\text { Conclusion } & 126\end{array}$

8 Monitoring and Control 129

Introduction 129

8.1 Inspection in public services 130

8.2 Inspection and local authority children's 132

8.3 The practice of reg. 22 visits 134

8.4 The practice of arm's length inspection visits $\quad 140$

Conclusion 149

9 The Management of External Residential Placements 153

Introduction 153

9.1 The expanding role of markets for children's residential care 
9.2 Key issues in the management of external placements

9.3 Purchasing practices: the 12 case SSDs compared 159

9.4 Management practices in the 12 SSDs 162

Conclusion 177

10 Conclusion 181

Introduction 181

10.1 The external management of children's homes $\quad 182$

10.2 Emerging policy and guidelines 193

10.3 Implications for UK public services 195

Appendices

$\begin{array}{ll}\text { Appendix } 1 & 207\end{array}$

Appendix $2 \quad 208$

Bibliography 210

Index 224 


\section{List of Tables and Figures}

\section{Tables}

2.1 Initiatives in Residential Child Care 13

3.1 Sample frame 32

3.2 Population and children looked after

3.3 Trends in the use of children's residential care by case authorities 36

3.4 The organisational structures of the 12 case SSDs 37

3.5 Unplanned admissions to residential care and occupancy levels in case SSDs

3.6 Levels of specialisation in own residential care in case SSDs

4.1 Strategy and related meetings during one year in the children's division of an SSD 50

4.2 Strategic planning capabilities in the 12 SSDs 66

$\begin{array}{lll}5.1 & \text { Placement decision making } & 77\end{array}$

6.1 Line management structures in case authorities 99

6.2 Background of children's homes' line managers 104

8.1 The conduct of regulation 22 visits 135

9.1 Case authorities' residential care - own and other provision 1996/97 160

9.2 External placements - decision-making arrangements 163

9.3 Information held on the independent sector market for children's residential care $\quad 167$

9.4 Contract arrangements with independent sector providers $\quad 169$

9.5 Monitoring arrangements for external contracts 173

\section{Figures}

3.1 The external management of children's homes 30

$\begin{array}{lll}4.1 & \text { Creating and implementing strategic plans } & 68\end{array}$ 


\section{Acknowledgements}

The project on which this book is based received help and support from many sources.

The research was commissioned by the Social Care Division of the Department of Health. Throughout the project, the team was given wise counsel by Carolyn Davies in Research and Development. We are extremely grateful for not only her patience and diligence but, above all, for the way that she championed this example of the introduction of management scholarship into her field. Her colleague, John Rowlands, was a valued provider of questions and promptings as well as sharing with us his statistical knowledge of the sector.

The project team also had the advantage of a Department of Health advisory group during the course of the research. The group included David Behan, Valerie Brasse, Carolyn Davies, John Rowlands, Lionel Took and Dorothy Whittaker. We are indebted to the group for the range of its advice and the appreciation shown of the particular demands of the project.

As newcomers to the field of children's care, we have been the beneficiaries of generous assistance from many established scholars in the sector. Jane Aldgate, Lesley Archer, David Berridge, Roger Bullock, Leslie Hicks, Michael Little, David Quinton, Wendy Rose and Ian Sinclair are deserving of special thanks for sharing their expertise so readily and engaging with our work so fully.

Professionals in the sector were equally forthcoming with their knowledge and experience. Phil Green and Ruth Newton of the SSI were kind enough not only to support our work but also to respond to our findings as they emerged during the project and, in particular as they were presented at regional events organised by the inspectorate. Moira Gibb, in her capacity as Chair of the Association of Directors of Social Services, was notable for her backing of our study and for using some of the results through the Association.

The authors are also grateful for the fieldwork carried out by Dianne Owen, prior to her retirement from the project due to ill health. Lesley Plowman and Gill Powell provided excellent secretarial assistance.

Thanks are also due to the comments received on the initial manuscript during the anonymous refereeing process organised by Palgrave 
Macmillan. We would also like to record our appreciation of the work of our editors at Palgrave Macmillan, Briar Towers and Jennifer Nelson, in bringing this book to print.

Notwithstanding such welcome help, the responsibility for the text remains, of course, with the authors. 